\title{
PENGARUH SPIRITUAL EMOTIONAL FREEDOM TECHNIQUE (SEFT) TERHADAP PENURUNAN KADAR GULA DARAH PENDERITA DIABETES MELLITUS TIPE 2 DI RSUD KOTA SURAKARTA
}

\author{
Ros Endah Happy Patriyani ${ }^{1}$, Sunarsih Rahayu ${ }^{1}$ \\ Kementerian Kesehatan Politeknik Kesehatan Surakarta Jurusan Keperawatan \\ Diterima : 13 Oktober 2018, Disetujui : 30 Oktober 2018 \\ e-mail: patriyanihappy@gmail.com
}

\begin{abstract}
Backgound: The incidence and severity levels of Diabetes Mellitus (DM) can be reduced through life style modification. The nurses' ability in complementary modalities can help the patients to modify their life style by managing the stress levels; doing standard medical cares to help reducing and controlling blood sugar levels. One form of complementary modalities is SEFT. SEFT is one relaxation technique that can reduce anxiety and optimally reduce blood sugar level. Relaxation can affect hypothalamus to regulate and decrease the activity of the sympathetic nervous system. The purpose of this research is to find out the impact of SEFT to the decrease blood sugar levels on type 2 DM patients. Method: The method applied in the research was quasi-experimental pre-posttest with control group. The research population was 100 type 2 DM patients (50 respondents as intervention group and 50 respondents as control group). Samples were taken using purposive sampling method. The data was analyzed using $t$ dependent test. Result: The result of the research shows that SEFT can reduce blood sugar levels of the type 2 DM patients with the value of $p=0.000$, and there was 220.060 points of blood sugar level reduction Conclusion: Nurses should teach type 2 DM patients to do SEFT; to monitor the blood sugar levels before and after SEFT.
\end{abstract}

Keywords: SEFT, Blood Sugar Level, Type 2 Diabetes Mellitus.

\section{PENDAHULUAN}

Jumlah penderita Diabetes Mellitus (DM) dari tahun ke tahun cenderung mengalami peningkatan, hampir di semua negara di dunia dan telah mencapai jumlah wabah atau epidemik, sehingga DM merupakan penyakit Global endemic (Shaw, Sicre, Zimmet, 2010). Diperkirakan tahun 2025 Indonesia akan naik ke nomor lima terbanyak untuk kasus DM di dunia. Pada tahun 2030 prevalensi DM di Indonesia mencapai 21,3 juta orang dengan asumsi prevalensi DM pada daerah urban 12 juta $(14,7 \%)$ dan 8,1 juta $(7,2 \%)$ di daerah rural (Diabetes Care, 2004). Berdasarkan Diabetes Atlas 6th Edition tahun 2013, Indonesia menduduki peringkat ketiga jumlah penderita DM terbanyak di kawasan Asia setelah China dan India. Diperkirakan 5,6 \% penduduk Indonesia atau sekitar 8,5 juta orang menderita DM. Jumlah tersebut diperkirakan meningkat 14 juta orang atau sekitar $6,7 \%$ di tahun 2035 (Soegondo, 2014 dalam Gatot, 2014). Dari total angka tersebut sekitar 90\% adalah penderita DM tipe 2.

Tingginya prevalensi DM disebabkan oleh faktor risiko yang tidak dapat diubah misalnya jenis kelamin, umur, dan faktor 
genetik yang kedua adalah faktor risiko yang dapat diubah misalnya kebiasaan minum dan makan manis, tingkat pendidikan, aktivitas fisik, konsumsi alkohol, IMT, lingkar pinggang (Teixeria, 2011). Untuk menurunkan kejadian dan keparahan dari DM maka dilakukan pencegahan seperti modifikasi gaya hidup dan pengobatan seperti obat oral hiperglikemik dan insulin (Depkes RI, 2013). Modifikasi gaya hidup salah satunya adalah mengelola stres. Menurut Surwit (2002), teknik penanganan stres bila disertai dengan perawatan standar dapat membantu menurunkan kadar gula darah.

Perawat dapat membantu pasien DM untuk mengendalikan kadar gula darah dengan cara melakukan complementary modalities. Spiritual Emotional Freedom Technique (SEFT) adalah salah satu bentuk terapi komplementer. SEFT membantu pasien diberbagai masalah kesulitan yang dialami seseorang dalam berbagai sisi kehidupan. SEFT pengembangan dari EFT diperkenalkan pada tahun 1995 oleh Gary Craig. EFT adalah metode sederhana yang menekankan fokus pada masalah dalam diri individu disertai dengan menekan secara lembut pada titik akupuntur (tapping) di wajah, tubuh bagian atas dan tangan. EFT dapat membantu berbagai masalah emosi dan fisik. Metode SEFT adalah menyatukan diri dengan kekuatan Ilahi yang memungkinkan orang untuk menjadi lebih bahagia, lebih kepastian dalam hidup, hasilnya tidak mudah stres sehingga dapat meningkatkan kesehatan jiwa (Zainuddin, 2009). SEFT termasuk salah satu teknik relaksasi yang dapat mengurangi kecemasan dan secara optimal dapat menurunkan kadar gula darah. Relaksasi dapat mempengaruhi hipotalamus untuk mengatur dan menurunkan aktifitas sistem saraf simpatis. Terapi SEFT selama ini belum pernah diberikan pada pasien DM Tipe2. berdasarkan hasil wawancara dengan perawat di ruangan RSUD Kota Surakarta, penanganan di pelayanan kesehatan umumnya hanya terapi konvensional, belum mengajarkan terapi relaksasi, seperti SEFT.

\section{METODE PENELITIAN}

Penelitian ini bertujuan untuk mengetahui pengaruh SEFT terhadap penurunan kadar gula darah pada pasien diabetes tipe 2 di RSUD Kota Surakarta. Penelitian ini menggunakan metode penelitian eksperimen semu, dengan pendekatan one group pre and postest.

Penelitian dilakukan pada bulan April-Juli 2017 di RSUD Kota Surakarta. Sampel yang digunakan pada penelitian ini adalah pasien diabetes tipe 2 sebanyak 100 responden dibagi 2 kelompok, kelompok intervensi 50 responden dan kelompok kontrol 50 responden. Teknik sampling yang digunakan dalam penelitian ini adalah sample random sampling.

Kriteria inklusi pada penelitian ini adalah pasien rawat inap, maksimal memiliki tiga komplikasi yang umum terjadi pada DM tipe 2, menu dan porsi makan terkontrol, tingkat stress (normal sampai dengan ringan) diukur dengan kuesioner DASS 42, bersedia menjadi responden penelitian dengan mengisi lembar persetujuan (informed consent). Kriteria eksklusi pada penelitian ini adalah responden yang tidak mengikuti penelitan sampai proses selesai.

Untuk mengetahui pengaruh SEFT terhadap penurunan kadar gula darah pada pasien diabetes tipe 2 dengan uji $t$ dependen (paired t test). 


\section{HASIL PENELITIAN}

Rata-rata KGD sebelum diberikan SEFT adalah 390.52 dengan standar deviasi 126.139. Rata-rata KGD setelah diberikan SEFT adalah 170.46 dengan standar deviasi 72.568. Perbedaan ratarata penurunan KGD sebelum dan setelah diberikan SEFT adalah 220.060 dengan standar deviasi 98.024. Hasil uji statistik didapatkan nilai $\mathrm{p}=0.000$, maka dapat disimpulkan bahwa SEFT dapat menurunkan KGD pada pasien diabetes tipe 2.

Tabel 1. Penurunan KGD sebelum dan sesudah diberikan SEFT $(\mathrm{N}=50)$

\begin{tabular}{ccccc}
$\begin{array}{c}\text { Penurunan } \\
\text { KGD }\end{array}$ & Mean & SD & SE & $\begin{array}{c}\text { P } \\
\text { Value }\end{array}$ \\
\hline Sebelum & 390.52 & 126.139 & 17.839 & .000 \\
Sesudah & 170.46 & 72.568 & 10.263 & \\
\hline
\end{tabular}

\section{PEMBAHASAN}

Hasil penelitian menunjukkan bahwa SEFT dapat menurunkan KGD pada pasien DM tipe 2 di RSUD Kota Surakarta. Point penurunan KGD pada pasien DM tipe 2 yang diberikan SEFT lebih tinggi dari pada point penurunan KGD pada pasien DM tipe 2 yang tidak diberikan SEFT.

Penelitian ini sesuai dengan penelitian Kuswandi A, Sitorus R, Gayatri D, yang berjudul "pengaruh relaksasi terhadap penurunan kadar gula darah pada pasien diabetes mellitus tipe 2 di sebuah rumah sakit di Tasikmalaya", bahwa relaksasi bagi pasien diabetes tipe 2 sangat mempengaruhi penurunan kadar gula darah, dibandingkan dengan yang tidak melakukannya.

Tujuan Penatalaksanaan DM jangka pendek adalah hilangnya keluhan dan tanda DM, mempertahankan rasa nyaman dan tercapainya target pengendalian glukosa darah. Sedangkan tujuan jangka panjang adalah tercegah dan terhambatnya progresivitas penyulit mikroangiopati, makroangiopati dan neuropati. Tujuan akhir pengelolaan DM Tipe 2 adalah turunnya morbiditas dan mortalitas DM. Untuk mencapai tujuan tersebut perlu dilakukan pengendalian glukosa darah, tekanan darah, berat badan dan profil lipid, melalui pengelolaan pasien secara holistik dengan mengajarkan perawatan mandiri dan perubahan perilaku (Buraerah, 2010). Empat pilar penatalaksanaan DM adalah edukasi, diet, latihan jasmani dan farmakologis. Salah satu edukasi yang dapat dilakukan adalah melatih SEFT.

SEFT merupakan salah satu teknik relaksasi. Teknik relaksasi dapat membantu menurunkan kadar gula darah pada pasien diabetes karena dapat menekan pengeluaran hormon-hormon yang dapat meningkatkan kadar gula darah, yaitu epinefrin, kortisol, glokagon, adreno cortico tropic hormonen (ACTH), kortikosteroid dan tiroid (Smeltzer, Bare, Hinkle, \& Cheever, 2008).

Epinefrin beraksi pada hati meningkatkan konversi glikogen menjadi glukosa dalam keadaan stress. Sedangkan kortisol memiliki efek meningkatkan metabolisme glukosa, sehingga asam amino, laktat, dan pirufat diubah di hati menjadi glukosa (glukoneogenesis) akhirnya menaikkan kadar gula darah. Glukagon meningkatkan kadar gula darah dengan cara mengkonversi glikogen di hati (bentuk karbohidrat yang tersimpan pada mamalia) menjadi glukosa, sehingga gula darah menjafdi naik. ACTH dan glukokortikoid pada korteks adrenal dapat meningkatkan kadar gula darah dengan cara meningkatkan pembentukan glukosa 
baru oleh hati. ACTH dan glukokortikoid juga meningkatkan lipolisis dan katabolisme karbohidrat (Smeltzer, Bare, Hinkle, \& Cheever, 2008).

Relaksasi dapat menurunkan kadar gula darah pada pasienn diabetes dengan cara menekan kelebihan pengeluaran hormon-hormon yang dapat meningkatkan kadar gula darah, yaitu epinefrin, kortisol, glukagon, adreno cortico tropic hormonen (ACTH), kortikosteroid dan tiroid (Smeltzer, Bare, Hinkle, \& Cheever, 2008).

Relaksasi dapat membantu menurunkan kadar gula darah dengan cara : (1) Menekan pengeluaran epinefrin sehingga menghambat konversi glikogen menjadi glukosa, (2) Menekan pengeluaran kortisol menghambat metabolisme glukosa, sehingga asam amino, laktat dan pirufat tetap di simpan di hati dalam bentuk glikogen sebagai energi cadangan, (3) Menekan pengeluaran glukagon menghambat mengkonversi glikogen dalam hati menjadi glukosa, (4) Relaksasi dapat menekan ACTH dan glukokortikoid pada korteks adrenal sehingga dapat menekan pembentukan glukosa baru oleh hati, selain itu lipolisis dan katabolisme karbohidrat dapat ditekan yang dapat menurunkan kadar gula darah (Smeltzer, Bare, Hinkle, \& Cheever, 2008).

\section{KESIMPULAN DAN SARAN}

SEFT dapat menurunkan KGD pada pasien DM tipe 2 dengan nilai $\mathrm{p}=0.000$, dan terjadi penurunan KGD 220.060 point.

Rata-rata SEFT dapat menurunkan KGD pada pasien DM tipe 2 di RSUD Kota Surakarta dengan point penurunan KGD lebih tinggi dari pada point penurunan KGD pada pasien DM tipe 2 yang tidak diberikan tindakan SEFT. Pasien DM tipe 2 dengan dukungan perawat dan keluarga supaya mempertahankan dan lebih ditingkatkan lagi motivasinya dalam melakukan SEFT baik selama dirawat di rumah sakit maupun di rumah, agar dapat menurunkan KGD yang tinggi maupun mempertahankan KGD yang sudah stabil atau normal. Perawat hendaknya memberi dukungan pada pasien DM tipe 2, mengajarkan dan memotivasi pasien untuk melakukan SEFT, serta memantau KGD sebelum dan sesudah melakukan SEFT.

\section{DAFTAR RUJUKAN}

ADA. (2013). Standards of Medical Care in Diabetes 2013. Diabetes Care.

DepKes RI. (2013). Pedoman Konseling pelayanan Kefarmasian di Sarana Kesehatan. Direktorat Bina Farmasi Komunitas Dan Klinik.Direktorat Jendral Bina Kefarmasian Dan Alat Kesehatan. Jakarta: DepartemenKesehatan RI.

Gatot. (2014). Indonesia Peringkat 3 Besar Pengidap Diabetes di Asia http://radarpena.com/read/ 2014/11/10/12918/3/7/IndonesiaPeringkat-3-Besar-PengidapDiabetes-di-Asia diakses 8 Maret 2017.

Kementerian Kesehatan. (2010). Petunjuk Teknis Pengukuran Faktor Risiko DM.

Kuswandi A, Sitorus R, Gayatri D. (2012). Pengaruh Relaksasi Terhadap Penurunan Kadar Gula Darah Pada Pasien Diabetes Mellitus Tipe 2 Di Sebuah Rumah Sakit Di Tasikmalaya. http://jki.ui.ac. id/index.php/jki/article/download/2 08/461. Diakses 5 Oktober 2017. 
Sastroasmoro, S \& Ismael, S. (2010).

Dasar-dasar metodologi penelitian klinis. Edisi ketiga. Jakarta: CV. Sagung Seto.

Shaw JE, Sicree RA, Zimmet PZ. 2010. Global estimates of the prevalence of diabetes for 2010 and 2030. Diabetes research and clinical practice $87 . \quad \mathrm{p}$ 4-14. www.elsevier.com/locate/diabres.

Smeltzer, $\quad$ S., $\quad$ Bare,B.,,Hinnkle,J., Cheever,K. (2008). Brunner and Suddarth' textbook of medical surgical nursing (11 th ed.). Philadelphia:Lippincott Williams $\&$ Wilkins.

Soegondo, S. (2010). Penatalaksanaan Diabetes Mellitus Terpadu. Jakarta: Balai Penerbit FK UI.

Surwit, R., et al. (2002). Stress Management Improves Long Term Glycemic Control in Type 2 Diabetes. Diabetes Care, 25 (2), pp 835-839.

WHO, Media Centre. Nocommunicable diseases. Updated March 2013. Access 18 Maret 2016. http://www. who.int/mediacentre/factsheets/fs 355/en/

WHO. (2013). Diabetes; Fact sheet. Department of Sustainable Development and Healthy Environments. South-East Asia: Regional Office.

Zainuddin, A. F. (2009).. Spiritual Emotional Freedom Technique $($ SEFT) for Healing + Success + Happiness + Greatness. Jakarta: Afzan Publishing. 